\title{
Effect of Moisture Content on Physical Properties of Soybean
}

\author{
Avinash Kakade*, Smita Khodke, Suhas Jadhav, Madhuri Gajabe and Nilza Othzes \\ Department of Agricultural Process Engineering, College of Agricultural Engineering and \\ Technology, V.N.M.K.V., Parbhani-431401, India \\ *Corresponding author
}

\begin{abstract}
A B S T R A C T
Soybean (Glycine $\max (\mathrm{L}))$ is one of the oldest principal food crops and has paramount importance in Indian agricultural and oil industry. Soybean is recognized for its value in enhancing and protecting health. Soybean has a tremendous potential to be transformed into a number of traditional local foods. Different products can be prepared from soybean such as soymilk and soy-paneer (dairy analogs), soy flour, soy bakery products, soynuts etc.The physical properties of soybean are important to design the equipments and machines for sorting, separation, transportation, processing and storage. Designing of such equipments and machines without taking these into considerations may yield poor results. For this reason the determination and considerations of these properties become an important role. The major moisture-dependent physical properties of biological materials are shape, size, mass, bulk -density, true-density, porosity and static coefficient of friction against various surfaces. The study was conducted to investigate some physical properties of soybean at various moisture levels. The dependence of physical properties of soybean on moisture content was determined. In the moisture range from 9.98- 27.10\% (wb).The soaked soybean size increased linearly in length $(6.34-8.95 \mathrm{~mm})$, width $(5.42-6.50 \mathrm{~mm})$, and thickness $(4.23-5.35 \mathrm{~mm})$ according to final moisture content. In this study, length, width and thickness models based on moisture content are defined as linear models and the regression coefficients $\left(R^{2}\right)$ related to these models are found between $0.84,0.72$ and 0.70 respectively. Arithmetic Mean Diameter (5.330 - $6.933 \mathrm{~mm}$ ), Geometric Mean Diameter (5.258 - 6.777mm), Square Mean Diameter (9.171- $11.876 \mathrm{~mm})$, Equivalent Diameter $(6.586-8.526 \mathrm{~mm})$ are computed from the average values of three principal dimensions. In the current study, it was determined that unit volume $\left(78.352-173.084 \mathrm{~mm}^{3}\right)$, surface area $\left(89.411-153.243 \mathrm{~mm}^{2}\right), 1000$ grain weight $(120.2-132.432 \mathrm{~g})$ and angle of repose $\left(25.25^{\circ}-30.08^{\circ}\right)$ increases as the moisture content of soaked soybean increases. As the moisture content of the soaked soybean increases, the value of sphericity, aspect ratio, bulk density, true density and porosity decreased.
\end{abstract}

\begin{tabular}{|l|}
\hline Ke y w o r d s \\
Moisture content, \\
$\begin{array}{l}\text { Physical properties, } \\
\text { Soybean, India }\end{array}$ \\
\hline Article Info \\
\hline $\begin{array}{l}\text { Accepted: } \\
15 \text { March } 2019 \\
\text { Available Online: } \\
10 \text { April } 2019\end{array}$ \\
\hline \hline
\end{tabular}

\section{Introduction}

Soybean is one of the oldest food sources known to the human beings. Though soybean is a legume crop, yet it is widely used as oilseed. It is now the second largest oilseed in India after groundnut. On an average, it 
contains about $40 \%$ protein, $23 \%$ carbohydrates, $20 \%$ oil, $5 \%$ mineral, $4 \%$ fibre and $8 \%$ moisture. Soybean is recognized for its value in enhancing and protecting health. Soy protein has all the eight essential amino acids. The recent discovery of the value of soy-isoflavones and their role in disease prevention has created the special interest of human beings in soybean. Lipid and protein are two major components of soybean. Human easily digest soy protein products. It has boundless food potential. However, soybean also contains some anti-nutritional factors like trypsin inhibitor, urease, flatulence factors, etc. hence soybean requires careful processing before utilization (Kulkarni et al., 2009). Soybean plays a major role in the world food trade. As per survey conducted by SOPA, in the whole world estimated production for soybean 2017-18 was 348.467million MT (MMT) as compared to 351.315 MMT of soybean 2016-17, which means a decrease in 2.848 percent over previous year. India ranks $5^{\text {th }}$ in area and production of soybean after US, Brazil, Argentina and China. The contribution of India in world soybean area and production is about $10.4 \%$ and $4.4 \%$ respectively. SOPA along with other associate agencies conducted extensive crop survey in three major soybean producing States of Madhya Pradesh, Maharashtra and Rajasthan. In Madhya Pradesh the Area under soybean cultivation during 2016-17 was 54.01lac ha as compared to 34.12 lac ha during 2015-16 showing an increase of $19.89 \%$. In Maharashtra the area under soybean cultivation during 2016-17 is 35.80 lac ha as compared to 22.00 lac hectare during 2015-16 showing an increase of 13.80 $\%$. The yield was $1059 \mathrm{Kg}$ per ha, resulting into a production of 57.17 Lac MT during 2016-17 in states of Madhya Pradesh, while in Maharashtra the yield was $1102 \mathrm{Kg}$ per ha, resulting into a production of $39.455 \mathrm{Lac}$ MT during 2016-17. The state like Madhya Pradesh, Maharashtra and Rajasthan together contributes about 97\% total area and 96\% production of soybean in the country (The Soybean Processors Association of India SOPA: 2017-18, Oilseeds - World Markets and Trade, a USDA Publication) (Anonymous, 2018a).

The physical properties of soybean are important to design the equipments and machines for sorting, separation, transportation, processing and storage. Designing of such equipments and machines without taking these into considerations may yield poor results. For this reason the determination and considerations of these properties become an important role. The major moisture-dependent physical properties of biological materials are shape, size, mass, bulk density, true density, porosity and static coefficient of friction against various surfaces (Mohsenin, 1980). In recent years, many researchers have investigated these properties for various agricultural crops such as lentil grains (Carman, 1996), locust bean seed (Olajide and Ade-Omowage, 1999; Ogunjimi et al., 2002), pumpkin seeds (Joshi et al., 1993), sunflower seeds (Gupta and Das, 1997), legume seeds (Altuntaş and Demirtola, 2007) and Faba bean (Altuntaş and Yıldız, 2007).

In addition, engineering and aerodynamic properties of soybean have been determined by Polat et al., (2006) and Isik (2007). But there is limited information on properties of soybean which is inadequate to design equipment and machines in scientific literatures for soybean to be cultivated in India. In considering this, the study was undertaken to investigate some physical properties of soybean at different moisture content level. The properties studied includes size distribution, AMD, GMD, SMD, EQD, sphericity, bulk density, true density, aspect ratio, thousand grain mass, angle of repose and porosity. 


\section{Materials and Methods}

Soybean (JS-335) was procured from the Seed Processing Unit of Vasantrao Naik Marathwada Krishi Vidyapeeth, Parbhani, Maharashtra State (India). The soybean grains were manually cleaned to remove foreign matter, dust, dirt, broken and immature grains.

\section{Measurement of physical properties of soybean}

The physical properties of soybean were important to design the equipment's and machines for sorting, separation, transportation, processing and storage. Physical properties such as length, width and thickness of soaked soybean grain was considered for designing puffing cum popping machine. Bulk density of soaked soybean was determined at various moisture content level was considered while designing the feed hopper.

\section{Thousand grain weight}

$1 \mathrm{~kg}$ of soybean grains were roughly divided into 10 equal portions and then 1000 numbers of soybean grains were randomly picked from each portion and weighed using a digital electronic balance having an accuracy of $0.001 \mathrm{~g}$. Three replications were carried out to determine the mean value of weight of soybean grain (Khedekar, 2013).

\section{Moisture content}

Moisture content of the soaked soybean was determined at frequent interval of 15 minute. 10 gram of soybean was immersed in water in (1:3) ratio in a $250 \mathrm{ml}$ of beaker. Such 25 beakers were prepared and 10 gram of soaked soybean was taken out of the each $250 \mathrm{ml}$ beaker at 15 minute time intervals. Surface water was removed from the grain with the help of tissue paper. Further moisture content of soaked soybean was determined in three replicates using the air oven method according to the ASAE Standard S352.2 (ASAE, 1997) for soybean.

Moisture content $(\%)=$

Initial weight $(\mathrm{g})$ - Final weight $(\mathrm{g})$

Initial weight $(\mathrm{g})$ X 100

Determination of length (L), width (W) and thickness (T) of soaked soybean

Length, width and thickness of soaked soybean was determined at 15 minute interval of time when soaked in water at 1:3 ratio. In order to determine dimensions, one hundred soaked soybean grains were randomly selected after every 15 minute time interval. For each soybean grain, the three principle dimensions, namely length, width and thickness were measured using a vernier caliper (Model: CD-15CPX, Mitutoyo Corp Made in Japan) having the least count of $0.001 \mathrm{~mm}$. The length (L) was defined as the distance from the tip cap to kernel crown. Width (W) was defined as the widest point to point measurement taken parallel to the face of the kernel. Thickness (T) was defined as the measured distance between the two kernels faces as described by Pordesimo et al., (1990).

The values of arithmetic mean diameter (AMD), geometric mean diameter (GMD), square mean diameter (SMD), equivalent diameter (EQD), degree of sphericity (Sp), aspect ratio (AR), shape factor $(\lambda)$ and unit volume of soaked soybean grains were computed by using the following equations (Mohsenin,1980; Deshmukh, 2016).

$\begin{aligned} \text { AMD } & =\frac{\mathrm{L}+\mathrm{W}+\mathrm{T}}{3} \\ \text { GMD } & =\sqrt[3]{\mathrm{LWT}}\end{aligned}$ 


$$
\begin{aligned}
& \mathrm{SMD}=\sqrt{\mathrm{LW}+\mathrm{WT}+\mathrm{TL}} \\
& \mathrm{EQD}=\frac{\mathrm{AMD}+\mathrm{GMD}+\mathrm{SMD}}{3} \\
& \mathrm{~S}_{\mathrm{p}}=\frac{\mathrm{GMD}}{\mathrm{L}} \\
& \mathrm{AR}=\frac{\mathrm{W}}{\mathrm{L}}
\end{aligned}
$$

Major dimension was used to calculate the surface area (S) of single grain (Jain, 1997) as details below.

$\mathrm{S}=\frac{\pi \times \mathrm{KMD} \times \mathrm{L}^{2}}{2 \mathrm{~L}-\mathrm{GMD}}$

The unit volume of single grain (Jain, 1997) was calculated as

$V_{t}=\frac{\pi \times G M D^{2} \times L^{2}}{6(2 L-G M D)}$

Where, $\quad \mathrm{V}_{\mathrm{t}}$ unit volume

L: length (mm)

GMD : geometric mean diameter

Shape factor $(\lambda)$ based on unit volume and surface area of grain was determined (Mc. Cabe and Smith, 1984) as

$\lambda=\frac{b}{a}$

$\mathrm{a}=\frac{\mathrm{Vt}}{\mathrm{W}^{4}} \mathrm{~b}=\frac{\mathrm{s}}{6 \mathrm{~W}^{2}}$

Where,

$\mathrm{V}_{\mathrm{t}}$ : unit volume $\mathrm{W}$ : width $\mathrm{S}$ : surface area $\left(\mathrm{mm}^{2}\right)$

\section{Bulk density, true density and porosity of soaked soybean}

The bulk density of soaked soybean was determined at 15 minute interval of time when soaked in water at 1:3 ratio of the mass of soaked soybeans to its total volume. It was determined by filling a $1000 \mathrm{~mL}$ container with soaked soybean grains from a height of about $150 \mathrm{~mm}$, striking the top level and then weighing the content (Deshpande et al., 1993; Gupta and Das, 1997; Konak Carman and Aydin, 2002). True density of the soaked soybean was determined by the toluene displacement method. Soaked soybean grains (about $5 \mathrm{~g}$ ) was submerged in toluene in a measuring cylinder having an accuracy of 0.1 $\mathrm{mL}$, the increase in volume due to soaked soybean was noted as true volume of soaked soybean which was then used to determine the true density of the soaked soybean (Wandkar, 2013).

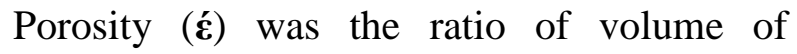
internal pores in the particle to its bulk volume. It was calculated as the ratio of the difference in the true density and bulk density to the true density and expressed by Mohsenin (1986):

$\dot{\varepsilon}=\frac{\rho t-\rho b}{\rho t}$

Where, $\rho t$ was the true density and $\rho b$ was the bulk density.

\section{Angle of repose}

The angle of repose is the characteristics of the bulk material which indicates the cohesion among the individual grains. The higher the cohesion, the higher the angle of repose. The angle of repose of soaked soybean was determined by using an open-ended cylinder 
of $15 \mathrm{~cm}$ diameter and $30 \mathrm{~cm}$ height. The cylinder was placed at the centre of circular plate having a diameter of $70 \mathrm{~cm}$ and was filled with soaked soybean grains. The cylinder was raised slowly until it formed a cone on the circular plate. The height of the cone was recorded. The angle of repose, $\theta$ was calculated by using the following formula (Wandkar, 2013).

$\theta=\tan -1(2 \mathrm{~h} / \mathrm{d})$

Where,

$\theta$ was the angle of repose, $h$ was the height of pile and $\mathrm{d}$ was the diameter of cone.

\section{Results and Discussion}

From Figure 1 it is clear that average values of the three principle dimension of raw soybean, namely length, width, thickness determined in this study at different moisture contents are presented in Table 1. Each principle dimension appeared to be linearly dependent on the moisture content as shown in Figure 1. Very high correlation was observed between the three principal dimension and length, width and thickness within the moisture range 9.98- 27.10\% (wb). The average length width and thickness of 100 grain varied from $6.34-8.95 \mathrm{~mm}, 5.42-$ 6.50 and $4.23-5.35 \mathrm{~mm}$ respectively, as the moisture content increased from 9.98-27.10\% (wb). Difference between values is statistically significant at $5 \%$ level of significance. This result indicated that the soaked soybean expanded in length, width, thickness and geometrical properties within the moisture range. The axial dimensions increased with increase in moisture content due to absorption of moisture, which resulted in swelling of capillaries, stretching of longitudinal ridges on the soaked soybean and finally expansion in medium and minor axes. Similar trends were showed for proso millet (Singh, 2018); (Deshmukh, 2016) and
(Jadhav, 2018) for soaked soybean. Figure 2 shows the effect of moisture content on average values of the three principle dimension of soaked soybean in terms of AMD, GMD, SMD and EQD.

The relationship between moisture content on sphericity and aspect ratio of soaked soybean is shown in Figure 3. The sphericity and aspect ratio of the soaked soybean decreased linearly depending on the increase of moisture content. Linearly negative change of sphericity and aspect ratio depending on the increase of moisture content can also be observed in some grainy products such as groundnut, peanut (Brayeh, 2001; Brayeh, 2002; Kibar, 2008) for soybean.

Surface area and volumetric change depending on moisture content of soaked soybean is shown in Figure 4. The surface area and volume of soaked soybean increased linearly with the increase of moisture content. The surface area and volume of soaked soybean increased from $89.411-153.243 \mathrm{~mm}^{2}$ and $78.352-173.084 \mathrm{~mm}^{3}$ respectively when moisture content changed from 9.98-27.10\% (wb). From Table 2 it is clear that the positive relationship between surface area and volumetric change with respect to moisture content of soaked soybean was also found by (Khedekar, 2013; Deshmukh, 2016).

It can be seen from Figure 5 that the thousand-grain mass increased from $120.2 \mathrm{gm}$ to $132.432 \mathrm{gm}$ with increase in moisture content in the specified moisture range. Similar trends were showed for proso millet (Singh, 2018); (Deshpande, 1993) and (Deshmukh, 2016) for soybean.

A plot of experimentally obtained values of bulk and true densities against moisture content (Fig. 6) indicated a decrease in bulk and true densities with an increase in moisture content in the specified moisture range. 
Table.1 Physical properties of soybean at various levels of moisture content

\begin{tabular}{|c|c|c|c|c|c|c|c|c|c|c|c|c|c|c|c|c|c|c|c|}
\hline Sr.No & $\begin{array}{l}\text { Soaking } \\
\text { Time } \\
\text { (min) }\end{array}$ & $\begin{array}{l}\text { Moisture } \\
\text { Content } \\
\text { (Wb\%) }\end{array}$ & $\begin{array}{l}\text { Lengt } \\
\text { h } \\
(\mathbf{m m})\end{array}$ & $\begin{array}{l}\text { Width } \\
\text { (mm) }\end{array}$ & $\begin{array}{l}\text { Thicknes } \\
\text { s (mm) }\end{array}$ & $\begin{array}{l}\text { AMD } \\
(\mathbf{m m})\end{array}$ & $\begin{array}{l}\text { GMD } \\
(\mathbf{m m})\end{array}$ & $\begin{array}{l}\text { SMD } \\
(\mathbf{m m})\end{array}$ & $\begin{array}{l}\text { EQD } \\
(\mathbf{m m})\end{array}$ & SP & Ar & $\mathrm{S}\left(\mathrm{mm}^{2}\right)$ & $\mathrm{Vt}\left(\mathrm{mm}^{3}\right)$ & $x$ & $\begin{array}{l}1000 \\
\text { grain } \\
\text { wt. (g) }\end{array}$ & $\begin{array}{l}\text { BD } \\
\left(\mathrm{Kg} / \mathrm{m}^{3}\right)\end{array}$ & $\begin{array}{l}\text { TD } \\
\left(\mathrm{Kg} / \mathrm{m}^{3}\right)\end{array}$ & PO\% & AOR \\
\hline 1 & 0 & 9.98 & 6.34 & 5.42 & 4.23 & 5.330 & 5.258 & 9.171 & 6.586 & 0.829 & 0.855 & 89.411 & 78.352 & 5.587 & 120.2 & 740.00 & 1192.00 & 37.919 & 25.25 \\
\hline 2 & 15 & 11.73 & 6.40 & 6.01 & 4.39 & 5.600 & 5.527 & 9.641 & 6.923 & 0.864 & 0.939 & 97.745 & 90.043 & 6.535 & 121.668 & 660.40 & 1140.10 & 42.075 & 27.30 \\
\hline 3 & 30 & 14.28 & 6.47 & 6.07 & 4.71 & 5.750 & 5.698 & 9.916 & 7.121 & 0.881 & 0.938 & 103.412 & 98.203 & 6.467 & 122.136 & 657.68 & 1131.62 & 41.881 & 27.42 \\
\hline 4 & 45 & 18.64 & 6.55 & 6.09 & 4.90 & 5.846 & 5.803 & 10.089 & 7.246 & 0.886 & 0.930 & 107.107 & 103.582 & 6.392 & 122.604 & 654.96 & 1123.13 & 41.685 & 27.54 \\
\hline 5 & 60 & 21.82 & 7.22 & 6.11 & 4.98 & 6.105 & 6.035 & 10.514 & 7.551 & 0.835 & 0.846 & 117.550 & 118.237 & 6.186 & 123.072 & 652.24 & 1114.65 & 41.485 & 27.66 \\
\hline 6 & 75 & 22.49 & 7.58 & 6.13 & 5.02 & 6.242 & 6.155 & 10.735 & 7.711 & 0.812 & 0.809 & 123.281 & 126.458 & 6.105 & 123.54 & 649.52 & 1106.16 & 41.282 & 27.78 \\
\hline 7 & 90 & 23.21 & 7.60 & 6.17 & 5.03 & 6.267 & 6.179 & 10.778 & 7.741 & 0.813 & 0.812 & 124.214 & 127.911 & 6.161 & 124.008 & 646.80 & 1097.68 & 41.076 & 27.91 \\
\hline 8 & 105 & 23.50 & 8.13 & 6.21 & 5.07 & 6.470 & 6.349 & 11.099 & 7.973 & 0.781 & 0.764 & 132.966 & 140.708 & 6.074 & 124.476 & 644.08 & 1089.20 & 40.866 & 28.03 \\
\hline 9 & 120 & 23.91 & 8.19 & 6.23 & 5.09 & 6.503 & 6.380 & 11.154 & 8.013 & 0.779 & 0.761 & 134.380 & 142.893 & 6.083 & 124.944 & 641.36 & 1080.71 & 40.654 & 28.15 \\
\hline 10 & 135 & 24.42 & 8.22 & 6.25 & 5.10 & 6.523 & 6.399 & 11.188 & 8.037 & 0.778 & 0.760 & 135.207 & 144.197 & 6.105 & 125.412 & 638.64 & 1072.23 & 40.438 & 28.27 \\
\hline 11 & 150 & 25.38 & 8.23 & 6.27 & 5.11 & 6.537 & 6.413 & 11.211 & 8.054 & 0.779 & 0.762 & 135.738 & 145.071 & 6.131 & 125.88 & 635.92 & 1063.74 & 40.219 & 28.39 \\
\hline 12 & 165 & 25.48 & 8.29 & 6.28 & 5.13 & 6.567 & 6.440 & 11.261 & 8.089 & 0.777 & 0.758 & 137.048 & 147.095 & 6.124 & 126.348 & 633.20 & 1055.26 & 39.996 & 28.51 \\
\hline 13 & 180 & 25.60 & 8.45 & 6.30 & 5.15 & 6.633 & 6.496 & 11.367 & 8.165 & 0.769 & 0.746 & 139.999 & 151.580 & 6.110 & 126.816 & 630.48 & 1046.78 & 39.769 & 28.63 \\
\hline 14 & 195 & 25.79 & 8.54 & 6.32 & 5.16 & 6.673 & 6.530 & 11.430 & 8.211 & 0.765 & 0.740 & 141.759 & 154.292 & 6.116 & 127.284 & 627.76 & 1038.29 & 39.539 & 28.75 \\
\hline 15 & 210 & 25.94 & 8.60 & 6.33 & 5.18 & 6.703 & 6.558 & 11.479 & 8.247 & 0.763 & 0.736 & 143.097 & 156.395 & 6.110 & 127.752 & 625.04 & 1029.81 & 39.305 & 28.87 \\
\hline 16 & 225 & 26.25 & 8.61 & 6.35 & 5.19 & 6.717 & 6.571 & 11.503 & 8.264 & 0.763 & 0.738 & 143.643 & 157.319 & 6.136 & 128.22 & 622.32 & 1021.32 & 39.067 & 28.99 \\
\hline 17 & 240 & 26.34 & 8.73 & 6.37 & 5.21 & 6.770 & 6.617 & 11.588 & 8.325 & 0.758 & 0.730 & 146.041 & 161.060 & 6.132 & 128.688 & 619.60 & 1012.84 & 38.825 & 29.12 \\
\hline 18 & 255 & 26.50 & 8.75 & 6.39 & 5.23 & 6.790 & 6.637 & 11.623 & 8.350 & 0.759 & 0.730 & 146.899 & 162.507 & 6.152 & 129.156 & 616.88 & 1004.36 & 38.580 & 29.24 \\
\hline 19 & 270 & 26.52 & 8.81 & 6.40 & 5.25 & 6.820 & 6.665 & 11.672 & 8.386 & 0.756 & 0.726 & 148.260 & 164.681 & 6.146 & 129.624 & 614.16 & 995.87 & 38.329 & 29.36 \\
\hline 20 & 285 & 26.68 & 8.84 & 6.42 & 5.26 & 6.840 & 6.683 & 11.706 & 8.410 & 0.756 & 0.726 & 149.129 & 166.113 & 6.167 & 130.092 & 611.44 & 987.39 & 38.075 & 29.48 \\
\hline 21 & 300 & 27.10 & 8.87 & 6.44 & 5.27 & 6.860 & 6.702 & 11.739 & 8.434 & 0.756 & 0.726 & 150.001 & 167.552 & 6.188 & 130.56 & 608.72 & 978.90 & 37.816 & 29.60 \\
\hline 22 & 315 & 27.10 & 8.91 & 6.45 & 5.29 & 6.883 & 6.724 & 11.778 & 8.462 & 0.755 & 0.724 & 151.061 & 169.290 & 6.187 & 131.028 & 606.00 & 970.42 & 37.553 & 29.72 \\
\hline 23 & 330 & 27.10 & 8.92 & 6.48 & 5.30 & 6.900 & 6.741 & 11.808 & 8.483 & 0.756 & 0.726 & 151.748 & 170.494 & 6.229 & 131.496 & 603.28 & 961.94 & 37.285 & 29.84 \\
\hline 24 & 345 & 27.10 & 8.93 & 6.49 & 5.32 & 6.913 & 6.756 & 11.832 & 8.500 & 0.757 & 0.727 & 152.339 & 171.525 & 6.235 & 131.964 & 600.56 & 953.45 & 37.012 & 29.96 \\
\hline 25 & 360 & 27.10 & 8.95 & 6.50 & 5.35 & 6.933 & 6.777 & 11.867 & 8.526 & 0.757 & 0.726 & 153.243 & 173.084 & 6.234 & 132.432 & 597.84 & 944.97 & 36.734 & 30.08 \\
\hline Avg & 180.0 & 23.5991 & 8.1251 & 6.259 & 5.0768 & 6.487 & 6.363 & 11.12 & 7.992 & 0.787 & 0.777 & 134.21 & 143.54 & 6.163 & 126.77 & 633.555 & 1048.51 & 39.498 & 28.55 \\
\hline SD & 110.3970 & 4.8573 & 0.8765 & 0.2240 & 0.2724 & 0.4452 & 0.4106 & 0.7380 & 0.5312 & 0.0412 & 0.0702 & 18.3040 & 27.1910 & 0.1664 & 3.5174 & 29.0909 & 65.8981 & 1.6379 & 1.084 \\
\hline SE & 22.0794 & 0.9715 & 0.1753 & 0.0448 & 0.0545 & 0.0890 & 0.0821 & 0.1476 & 0.1062 & 0.0082 & 0.0140 & 3.6608 & 5.4382 & 0.0333 & 0.7035 & 5.8182 & 13.1796 & 0.3276 & 0.216 \\
\hline $\begin{array}{l}\text { CD } \\
\mathbf{5 \%}\end{array}$ & 45.7927 & 2.0148 & 0.3636 & 0.0929 & 0.1130 & 0.1847 & 0.1703 & 0.3061 & 0.2203 & 0.0171 & 0.0291 & 7.5925 & 11.2788 & 0.0690 & 1.4590 & 12.0669 & 27.3345 & 0.6794 & 0.449 \\
\hline CV\% & 61.332 & 20.583 & 10.788 & 3.579 & 5.366 & 6.862 & 6.452 & 6.633 & 6.646 & 5.227 & 9.031 & 13.638 & 18.942 & 2.699 & 2.774 & 4.592 & 6.285 & 4.147 & 3.797 \\
\hline
\end{tabular}


Table.2 Regression equations for physical properties of soaked soybean

\begin{tabular}{|c|c|c|c|}
\hline Properties & Range & $\mathbf{m x}+\mathbf{c}$ & $\mathbf{R}^{2}$ \\
\hline Length (mm) & $6.34-8.95$ & $0.1089 x+6.709$ & 0.84 \\
\hline Width (mm) & $5.42-6.50$ & $0.0258 x+5.923$ & 0.72 \\
\hline Thickness (mm) & $4.23-5.35$ & $0.0309 x+4.675$ & 0.70 \\
\hline Arithmetic Mean Diameter (mm) & $5.330-6.933$ & $0.0552 x+5.769$ & 0.84 \\
\hline Geometric Mean Diameter (mm) & $5.258-6.777$ & $0.0505 x+5.7066$ & 0.83 \\
\hline Square Mean Diameter (mm) & $9.171-11.867$ & $0.0912 x+9.9407$ & 0.82 \\
\hline Equivalent Diameter (mm) & $6.586-8.526$ & $0.0656 x+7.113$ & 0.83 \\
\hline Degree of sphericity $\left(S_{p}\right)$ & $0.829-0.757$ & $-0.0047 x+0.8487$ & 0.72 \\
\hline Aspect ratio (AR) & $0.855-0.726$ & $-0.0079 x+0.8807$ & 0.70 \\
\hline Surface area $(S) \mathrm{mm}^{2}$ & $89.411-153.243$ & $2.301 x+104.3$ & 0.86 \\
\hline Unit volume of single grain $\left(V_{t}\right) \mathrm{mm}^{3}$ & $78.352-173.084$ & $3.4546 x+98.636$ & 0.88 \\
\hline Shape factor $(\chi)$ & $5.587-6.234$ & $0.001 x+6.1513$ & - \\
\hline 1000 grain weight $(\mathrm{g})$ & $120.2-132.432$ & $0.4772 x+120.57$ & 0.99 \\
\hline Bulk density $\left(\mathrm{Kg} / \mathrm{m}^{3}\right)$ & $740-597.84$ & $-3.4297 x+678.14$ & 0.76 \\
\hline True density $\left(\mathrm{Kg} / \mathrm{m}^{3}\right)$ & $1192-944.97$ & $-8.8848 x+1164$ & 0.98 \\
\hline Porosity \% & $37.91-36.734$ & $-0.1896 x+41.964$ & 0.72 \\
\hline Angle of repose $\left(^{0}\right)$ & $25.25-30.08$ & $0.1388 x+26.749$ & 0.88 \\
\hline
\end{tabular}

$\mathrm{x}$ : moisture content, $\% \mathrm{wb}$. 
Fig.1 Effect of moisture content on principal dimensions of soaked soybean

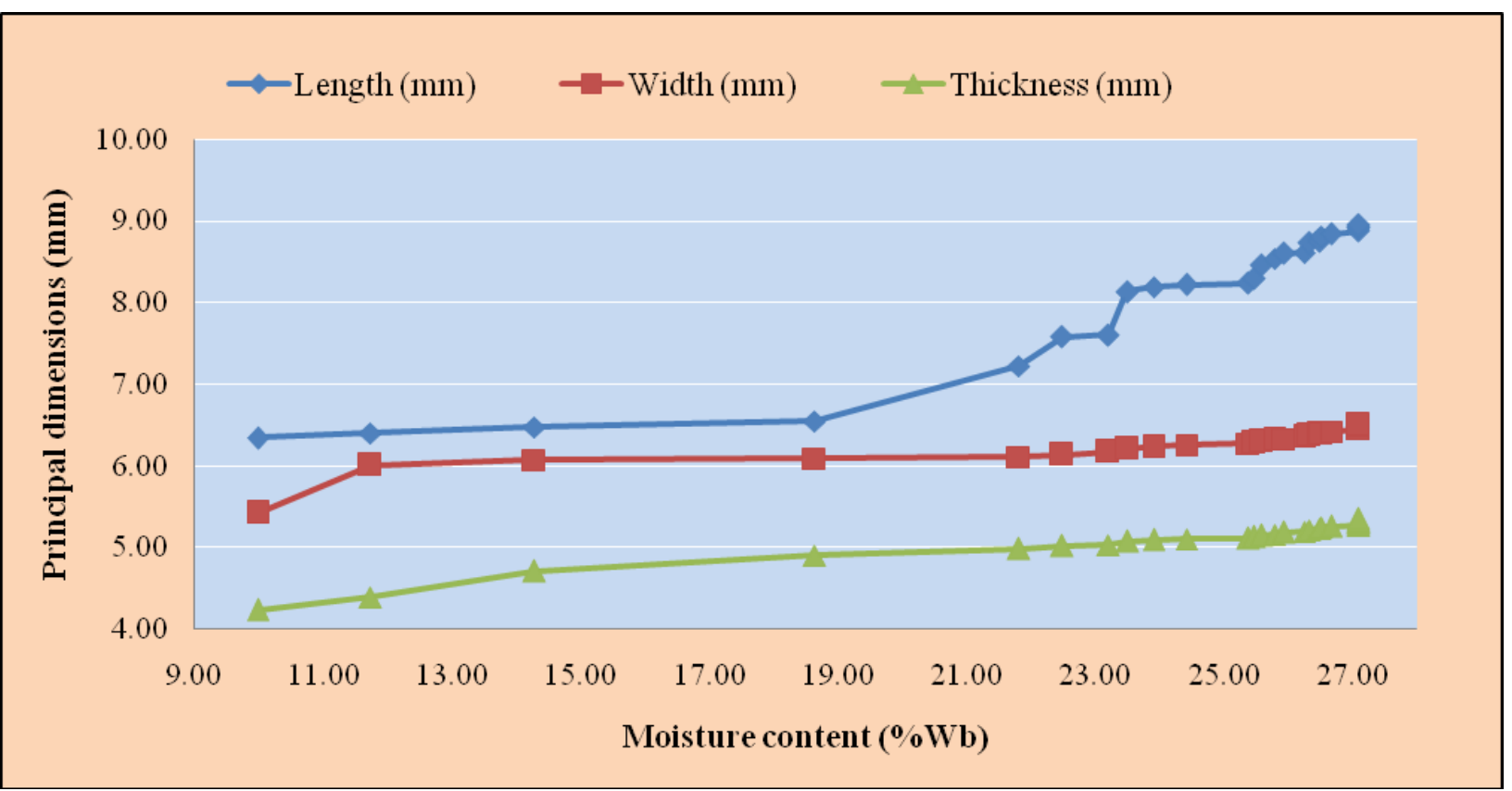

Fig.2 Effect of moisture content on average values of principal dimensions of soaked soybean

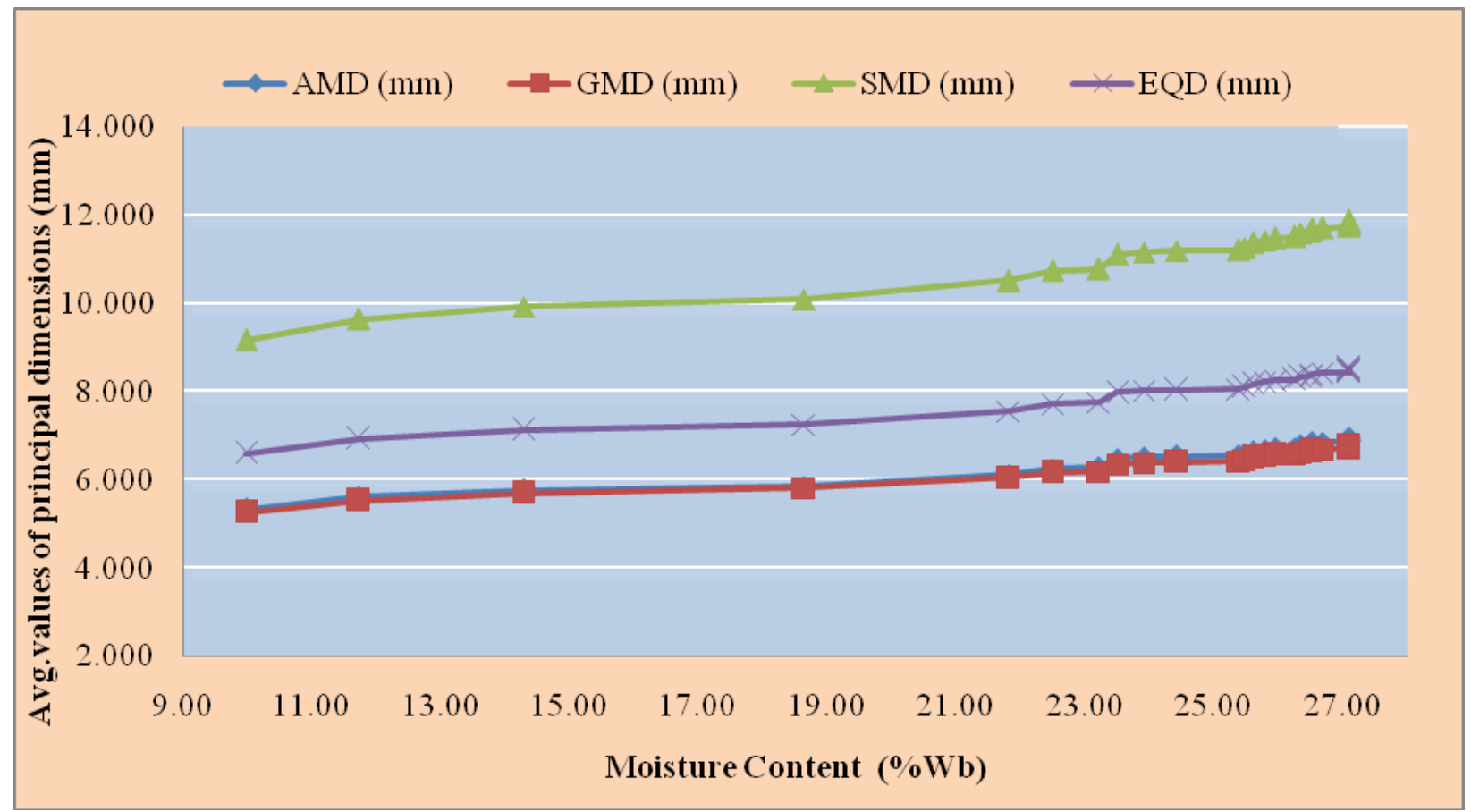


Fig.3 Effect of moisture content on degree of sphericity and aspect ratio of soaked soybean

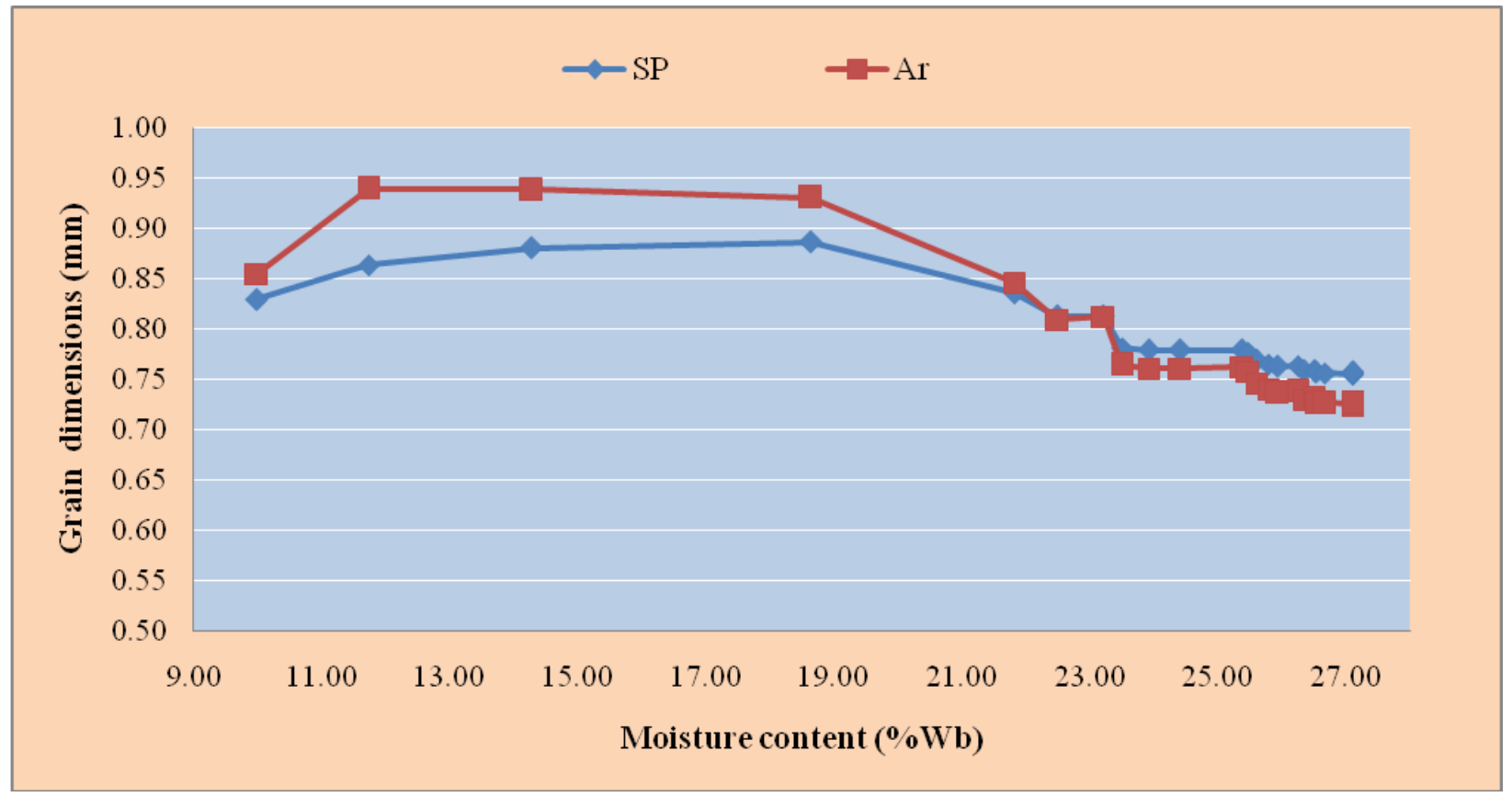

Fig.4 Effect of moisture content on surface area and unit volume of soaked soybean

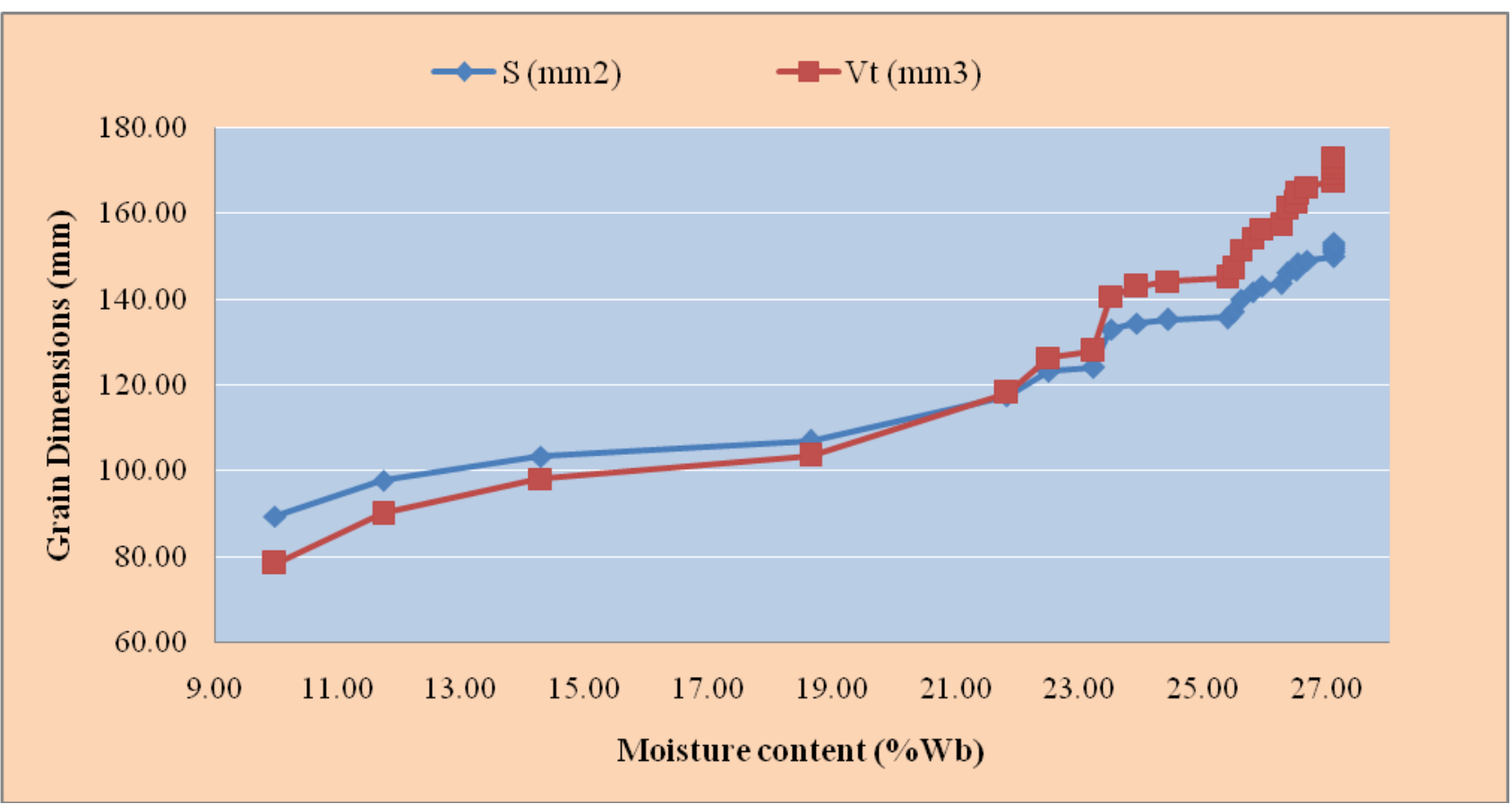


Fig.5 Effect of moisture content on 1000 grain wt. of soaked soybean

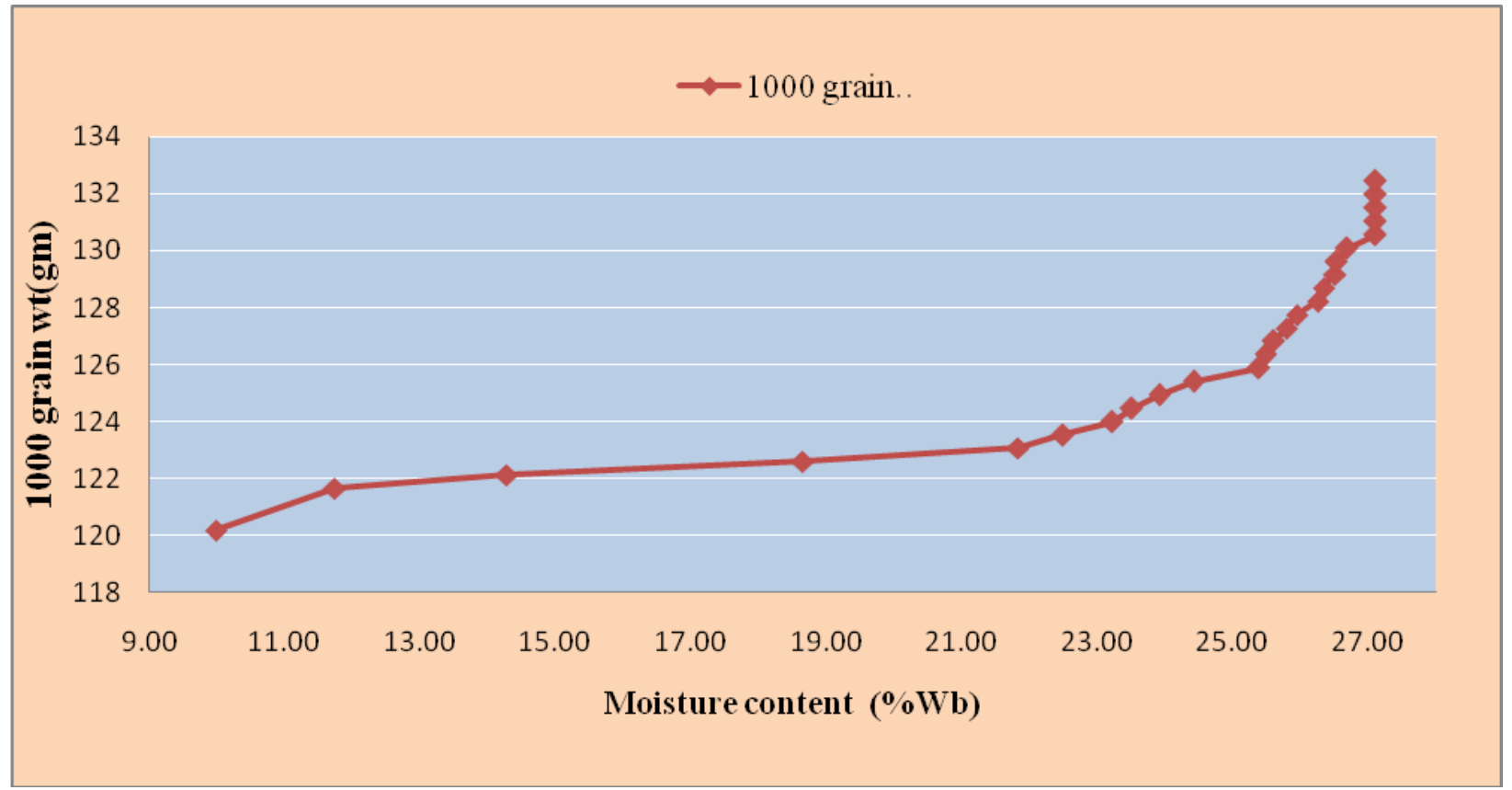

Fig.6 Effect of moisture content on bulk and true densities of soaked soybean

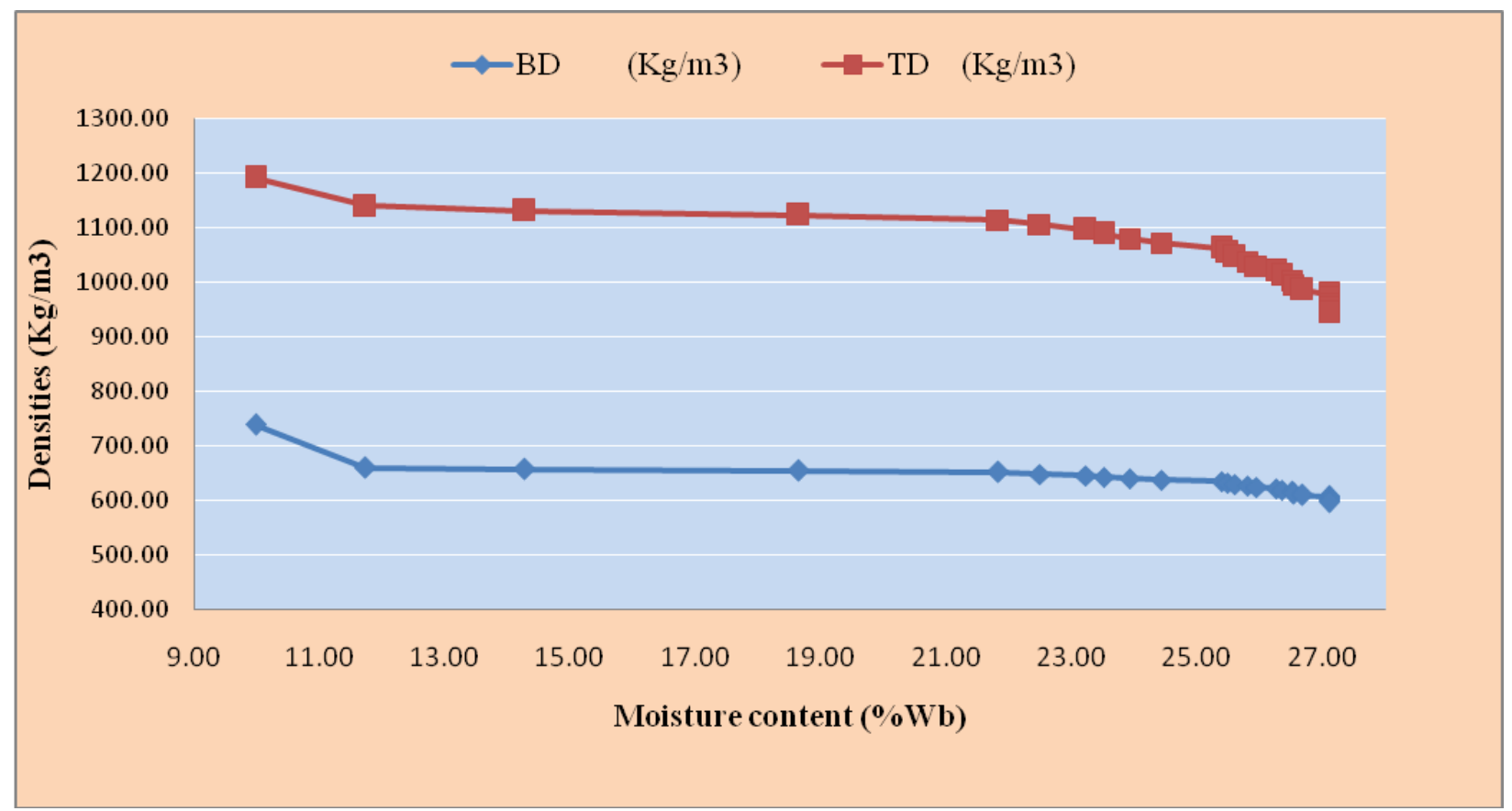


Fig.7 Effect of moisture content on porosity of soaked soybean

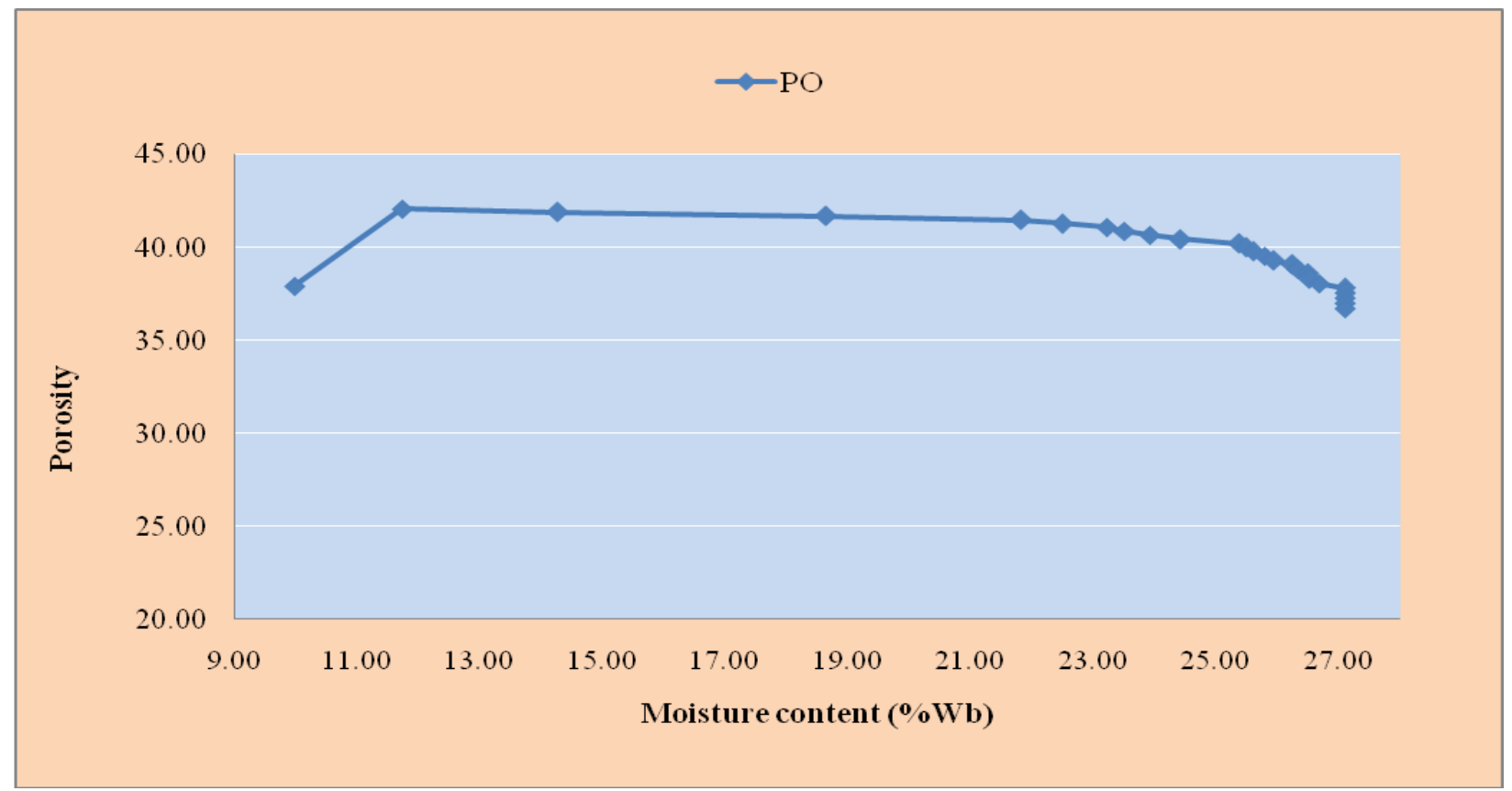

Fig.8 Effect of moisture content on angle of repose of soaked soybean

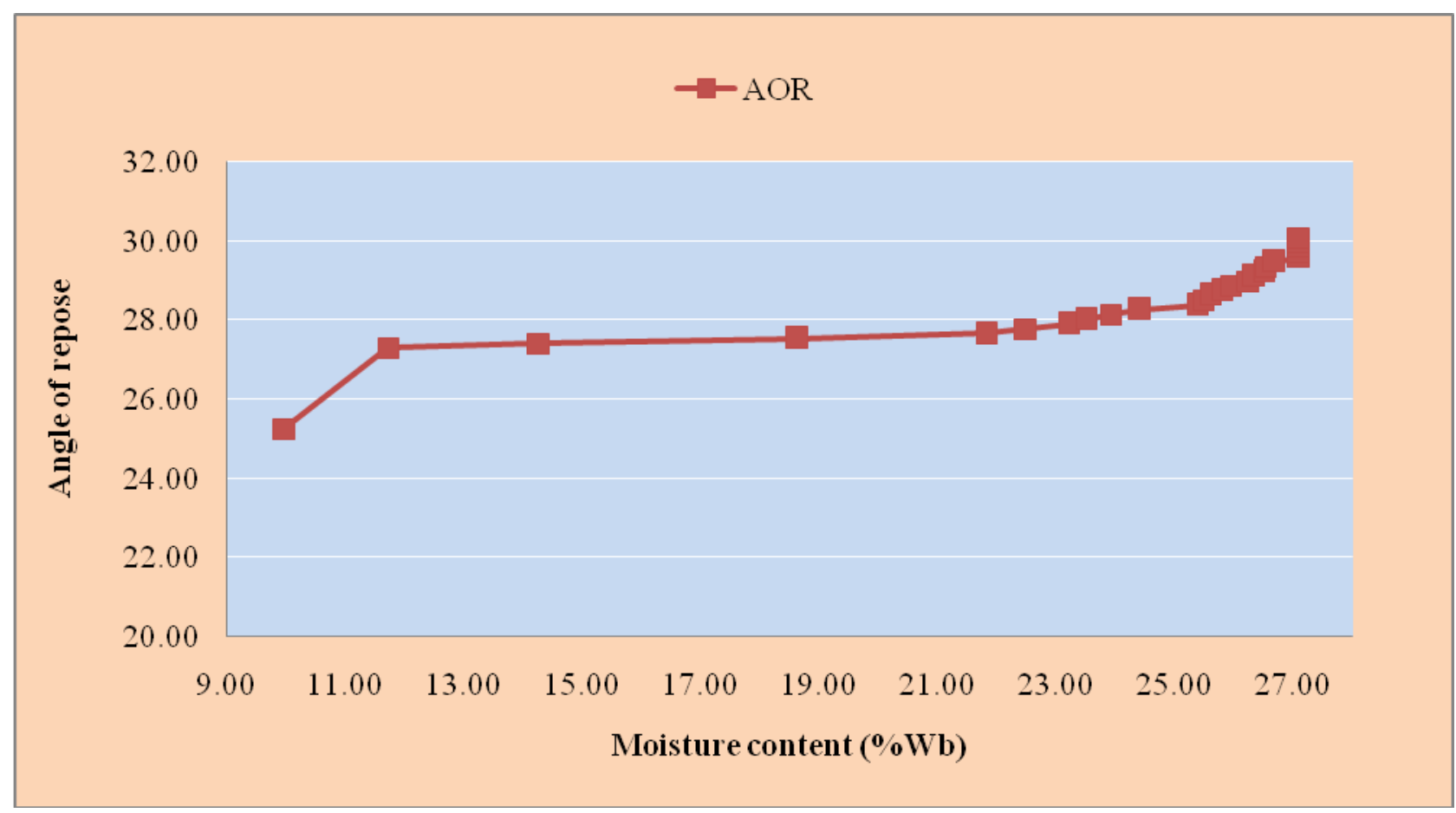

The similar decreasing trend in bulk and true densities against moisture content was reported by Deshpande (1993), Deshmukh (2016) and Jadhav (2018) for soybean. Since the porosity depends on the bulk as well as true densities, the magnitude of variation in porosity of soybean depend on moisture content factor. The porosity of soybean was found to decrease 
linearly with increase in moisture content from 9.98 to $27.10 \%$ (wb) (Fig. 7).

The experimental data obtained for angle of repose of soaked soybean is given in Table 1 . The angle of repose increases linearly with the increase in moisture content (Fig. 8). The value of angle of repose increases from 25.25 to 30.08 degrees as moisture content increases from 9.98 $\%$ to $27.10 \%$ (wb). Similar increasing trend was reported by Munde (1997) for green gram. The relationship between angle of repose $(\theta)$ and moisture content ( $\mathrm{x}$ ) can be expressed by regression equations as:

$\theta=0.1388 \mathrm{x}+26.749 R^{2}=0.88$

Where,

$\mathrm{x}$ : moisture content, $\% \mathrm{wb}$.

$(\theta)$ : angle of repose

All the dimensions and physical properties of soaked soybean were significantly and positively correlated to moisture content. A relationship was observed between moisture content to axial dimensions and physical properties as shown in Table 2 . The change in soybean dimension during soaking could be best expressed by a modified exponential relationship with the $\mathrm{R}^{2}$ for equation fitting, respectively. The results were statistically analyzed for all physical properties of soaked soybean.

Based on the results, following major conclusions have been drawn in the present investigation:

The average length, width and thickness of soybean grains ranged from 6.34 to $8.95 \mathrm{~mm}$, 5.42 to $6.50 \mathrm{~mm}$ and 4.23 to $5.35 \mathrm{~mm}$ as the moisture content increased from $9.98 \%$ to $27.10 \%$ (wb), respectively.

The geometric mean diameter increased from 5.258 to $6.777 \mathrm{~mm}$. The thousand grain mass increased from 120.2 to $132.432 \mathrm{~g}$ and the sphericity increased from 0.829 to 0.757 with the increase in moisture content from $9.98 \%$ to $27.10 \%$ (wb), respectively.

The bulk density decreased from 740 to 597.84 $\mathrm{kg} \mathrm{m}-3$, whereas the true density decreased from 1192 to $944.97 \mathrm{~kg} \mathrm{~m}-3$. While porosity decreased from 37.91 - 36.734 with the increase in moisture content from $9.98 \%$ to $27.10 \%$ (wb), respectively.

The angle of repose increased linearly from 25.25 to 30.08 degrees with the increase in moisture content.

\section{References}

Altuntaş, E., and Demirtola, H. (2007). Effect of moisture content on physical properties of some grain legume seeds. New Zealand Journal of Crop and Horticultural Science, 35(4): 423-433.

Altuntas, E. and Yildiz, M. (2007). Effect of moisture content on some physical and mechanical properties of faba bean (Vicia faba L.) grains. Journal of Food Engineering, 78:174-183.

Baryeh, E.A. (2001). Physical properties of bambara groundnuts. Journal Food Engg.,47: 321-326.

Baryeh, E.A. and Mangope, B.K. (2002). Some physical properties of QP-38 variety pigeon pea. Journal Food Eng., 56:59-65.

Carman, K. (1996). Some physical properties of lentil grains. Journal of Agricultural Engineering Research, 63(2): 87-92.

Anonymous a (2018). www.sopa.org

Deshpande, S.D., Bal, S. and Ojha, T.P. (1993). Physical properties of soybean. Journal of Agricultural Engineering Research, 56(2):89-98.

Deshmukh, C.G. (2016). Design and development of roaster for production of soynut. An unpublished M.Tech thesis submitted to Department of Agricultural Process Engineering, College of Agricultural Engineering and Technology, Parbhani-431401. 
Gupta, R. K., and Das, S.K. (1997). Physical properties of sunflower seeds. Journal of Agricultural Engineering Research, 66: 18.

Isik, E. (2007).Some engineering properties of soybean grains. American Journal of Food Technology, 2(3): 115-125.

Jadhav, S.S. (2018). Performance evaluation of multi-grain popper cum puffer for selected grains. An unpublished M.Tech thesis submitted to Department of Agricultural Process Engineering, College of Agricultural Engineering and Technology, Parbhani-431401.

Joshi, D. C., Das, S. D and Mukharjee, R.K. (1993). Physical properties of pumpkin seeds. Journal of Agricultural Engineering Research, 54: 219-229

Kibar, H. and Öztürk, T. (2008). Physical and mechanical properties of soybean. Department of Agricultural Structures and Irrigation, Faculty of Agriculture, University of Ondokuz Mayis. Journal of International Agrophysics, 22:239-244.

Khedekar, T.A. (2013). Design and development of roaster for soaked soybean. An unpublished M.Tech thesis submitted to Department of Agricultural Process Engineering, College of Agricultural Engineering and Technology, Parbhani-431401.

Khurmi, R.S. and Gupta, J.K. (2005). A textbook of Machine Design. Eurasia Publishing House (Pvt.) Ltd., Ram Nagar, New Delhi.

Kulkarni, S.D. and Bargale, P.C. (2009). Soybean production and utilization in
India status, prospects and the future strategy. Management of soy-based enterprises. Soybean processing and utilization center (SPU), Central Institute of Agricultural Engineering (CIAE) Bhopal:17-18.

Mohsenin, N. N. (1980). Physical properties of plant and animal materials. Gordon and Breach Science Publishers Inc, New York.

Munde, A.V. (1997). Effects of moisture content on physical properties of green gram. Journal of Maharashtra Agricultural Universities, 22 (3): 324327.

Olajide, J. O. and Ade-Omowage. (1999). Some physical properties of locust bean seed. Journal of Agricultural Engineering Research, 74 (2): 15-22.

Ogunjimi, L. A., Aviara, N. A. and Aregbesola O. A. (2002). Some engineering properties of locust bean seed. Journal of Food Engineering, 55 (2): 95-99.

Singh, K. P., Chandel, N. S., Potdar, R. R., Jat, D., Agrawal, K. N. and Hota, S. (2018).Assessment of Engineering Properties of Proso Millet (Panicum miliaceum).Journal of Agricultural Engineering,55 (2): 42-51.

Wandkar, S.V., Ukey, P., D. and Pawar, D.A. (2013). Determination of physical properties of soybean at different moisture levels. Farm Machinery Testing and Training Centre, Dr. A. S. College of Agricultural Engineering, Mahatma Phule Krishi Vidyapeeth, Rahuri, Ahmednagar, Maharashtra, 413722, India.

\section{How to cite this article:}

Avinash Kakade, Smita Khodke, Suhas Jadhav, Madhuri Gajabe and Nilza Othzes. 2019. Effect of Moisture Content on Physical Properties of Soybean. Int.J.Curr.Microbiol.App.Sci. 8(04): 17701782. doi: https://doi.org/10.20546/ijcmas.2019.804.206 